I paraphrase), "you quit loading the wagon when the mules are fixin to quit pullin."

\section{CONCLUSION}

Through theory and tools, scholars have built an extraordinary view of the Congress. Until now, I've had a bird's eye view of Congress. The Congressional Fellowship has provided a wonderful complement to such a view. There's no substitute for learning about congressional politics as a participant-observer. Indeed, the fellowship has given me the opportunity to experience Congress-to see members in their world. But the fellowship experience affected me in an unexpected way as well. Ever since that first day, I began to appreciate better some of the constraints members face, and have become more invested and hopeful in Congress.

\section{REF ER E N C E S}

Behre, Robert. 2007. "Mr. Clout." The Post and Courier, February 18, A1.
Brush, Silla. 2007. "Hidden Power on the Hill." U.S. News and World Report, March 15, 42-43.

Evans, C. Lawrence, and Claire E. Grandy. 2008. "The Whip Systems of Congress." In Congress Reconsidered, 9 th ed., ed. Lawrence C. Dodd and Bruce I. Oppenheimer. Washington, D.C.: CQ Press, 189-215

Fenno, Richard Jr. 1978. Home Style: House Members in Their Districts. New York: Harper Collins Publishers.

Rogers, David. 2008. "Clyburn Herds a Diverse Flock". Politico, June 19, 1-2.

Smith, Steven S. 2007. Party Influence in Congress. New York: Cambridge University Press.

\section{NOTES}

First and foremost, I want to thank my beautiful wife, Candace. Without her support and active encouragement, this wonderful experience would not have been possible. Moreover, if the richness of an experience can be gauged by the friendships one makes, than I've been truly fortunate with my time on the Hill. I'm greatly indebted to colleagues from Miami University, APSA, Congressman Clyburn, and my many friends in the whip's office and other offices on Capitol Hill. To all of you, thank you.

1 The Honorable James E. Clyburn is the House majority whip and represents South Carolina's
Sixth District.

2 The offices in the upper suites are beautifulsome with original painted mural ceilings and other detailed adornments that deserve greater description than I dare try here.

3 I don't dwell on constituency-representative relations in this article for the sake of brevity. But I will say that the whip and members more generally stay closely attuned with the constituents in their districts.

4 The clerk calls out each name and the respective vote change on the floor.

5 Indeed, the legislative productivity of the 111th Congress will likely compare well with some of the more important markers like Speaker Wright's 1ooth and Speaker Gingrich's 104th .

6 Congressman Clyburn's leadership role actually started rather early as he was elected president of his NAACP youth chapter at the age of 12 (http://clyburn.house.gov/clyburn-biography).

\title{
External Reviewers; Friends or Foes? Political Science Panel Embraces Reviewers!
}

\author{
Graham Wilson, Boston University
}

Tf $\mathrm{f}$ it is time for an external review-or if the dean announces you are having one anyway-it almost certain that your first reaction as a department chair will be that this is bad news and that the red coats are coming! After all, at very least an external review is going to result in a considerable amount of extra work. And the review can be a moment of what a panel member who had served as a dean termed a time of "extreme danger"; a bad review can really damage a departments standing and prospects with the dean and university administration more generally. However at the 2009 Annual Meeting a distinguished group of political scientists (Evelyn Huber, Stephen Majeski, John Woolley, Michael Kraft, and Gretchen Bauer) chaired by

Graham Wilson is a professor of political science and director of graduate studies at Boston University. He is the chair of APSA's Committee on Departmental Services.
Graham Wilson of the APSA Departmental Service Committee urged chairs to be positive. Having been on both the receiving and giving sides of the review process, panel members uniformly concluded that it can be a very positive experience for departments and their chairs.

Panel members recalled how they had seen external reviews prompt departments into making crucial decisions-in one case transforming a previously mediocre graduate program, and in another case confronting a difficult choice they had long avoided. The process of preparing for the review will prompt a department to think more seriously about its curriculum, its governance, and its priorities than it would otherwise. As one panelist argued, most departments get used to their established curriculum and ways of doing things even though there may be room for improvement: "There isn't a department that couldn't better than it is right now." External reviews can help a department chair advance a reform agenda. One former department chair thought that an external review had helped him advance his goals for reform and improvement in the department far beyond what he could have achieved had it been just the chair arguing for the department. Sometimes reviewers can be problem solvers, for example, seeing ways to help departments achieve their goals with what they had thought to be inadequate resources. One panelist had served on a review team that had seen a restructuring graduate program make what seemed like inadequate and unchangeable funding for graduate students stretch much further. And even though external reviewers are often told that it is pointless for them to ask for more resources for the department they are reviewing, their report can be the basis over the medium and long term on which a department can request them. A review that argues that the department is too weak in a major subfield to be fully successful makes a case 
that department chairs can invoke in the future to support hiring requests.

But although the panel thought that external reviews were usually valuable and beneficial for departments, it also had some warnings and advice.

First, chairs need to involve all the faculty and staff in the process. This is partly because otherwise the work of preparing for and handling the review will be overwhelming. It is also because it is essential to get a positive "buy in" to the process from the entire department. Indeed, this buy in should include students as well. One panel member noted that it is inevitable that dissatisfied students will turn up to meet the external review committee and it is important to make sure that the satisfied (we hope!) majority are also represented.

Second, departments need to make sure that the self-study they prepare as part of the review process is thorough and honest. Several panelists who had conducted external reviews reported that their committees had become very hostile to departments when key problems or issues had been ignored in the self-study or when a department makes an argument that doesn't seem consistent with the facts: "The department had a clear agenda that they kept pushing and that we did not buy. So we were hit over the head with an argument we didn't buy and that we didn't see the data and didn't accept. It left us with a very bad taste."

Third, chairs need to have a clear headed view themselves of where the department stands. How does the dean see the department and the contribution it makes? What are its strengths and weaknesses?

Fourth, it is counterproductive for chairs to try to manipulate what their colleagues say to the external review committee. Panelists told amusing stories of chairs who had made themselves (and their departments) look ridiculous as they tried to coach colleagues for presentations to the committee. However, it is important for the chair to talk with the review committee before its conclusions crystallize into the interim-usually verbal-report the committee makes to the dean or provost before leaving town and writing the official report. External review committees usually size up departments pretty accurately but as in all processes errors can be made or unrepresentative views given too much credence.

The panelists also had some advice for reviewers. One suggestion was not to destroy credibility with the university by making predictable and unrealistic demands for more resources: "If you write a report that says give them seven new FTEs when the university has told you that there aren't any new resources, you won't have an impact. The senior administrators will not take that advice or the rest of the report seriously." One panelist thought they had achieved more for a department by writing a report with different sets of recommendations, one assuming no new resources, one assuming modest new resources, and the third assuming significant new resources. This should not stop reviewers from pointing to areas in which the department is weak and thereby laying the groundwork for the department to argue its case for resources-as noted earlier. However, the review committee needs to be careful not to destroy its own credibility.

Another panelists emphasized that an external review is a review, not an evaluation, and in particular not an evaluation of individual faculty.

The most commonly emphasized recommendation to all sides was to keep a positive attitude to the review. People who serve on external review committees are usually intent on helping. Reviewers "tend to be problem solvers." They are nearly always successful and busy people "who don't have the time or inclination to serve as hit men for administrators." Approached positively, the external review is an opportunity for useful reflection and laying the groundwork for future growth.

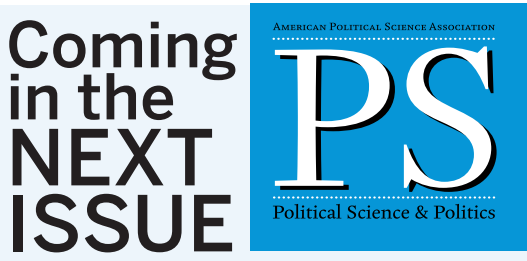

A preview of some of the articles that will be published in the April issue:

SYMPOSIUM

The Future of Congress

Colleen Shogan, guest editor

\section{FEATURES}

Usage of Recursive in Political Science Miles Townes

Stump Speeches and Road Trips: The Impact of State Campaign Appearances in Presidential Elections

Jeffrey S. Hill, Elaine Rodriquez, and Amanda E. Wooden

Did Bush Voters Cause Obama's Victory?

Arthur Lupia

The Effect of Nomination Divisiveness on the 2008 Presidential Election

Priscilla L. Southwell

THE PROFESSION

Symposium-Political Theorists Matthew J. Moore, guest editor

Trends in Funding for Dissertation Field Research: Why So Little Support for Political Science and Sociology? Rina Agarwala and Emmanuel Teitelbaum

The Representation of Women in Publication: An Analysis of Political Communication and the International Journal of Press/Politics

Heather K. Evans

THE TEACHER

Symposium-Teaching About the National Debt

Steven Galatas, guest editor

The University and Student Political Engagement

James R. Simmons

Standardizing Citizenship: The Potential Influence of State Standards on the Civic Development of Adolescents Wayne Journell

A Pilgrimage to the Disneyland of Faith Susan Jane McWilliams 